\title{
Population genetic structure and milk production traits in Girgentana goat breed
}

\author{
Salvatore Mastrangelo ${ }^{\mathrm{A}, \mathrm{B}}$, Marco Tolone ${ }^{\mathrm{A}}$, Maria Montalbano ${ }^{\mathrm{A}}$, Lina Tortorici ${ }^{\mathrm{A}}$, \\ Rosalia Di Gerlando ${ }^{\mathrm{A}}$, Maria Teresa Sardina ${ }^{\mathrm{A}}$ and Baldassare Portolano ${ }^{\mathrm{A}}$

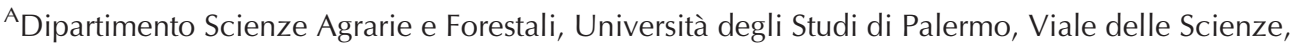 \\ Edificio 4, Ingresso G, 90128 Palermo, Italy. \\ ${ }^{\mathrm{B}}$ Corresponding author. Email: salvatore.mastrangelo@unipa.it
}

\begin{abstract}
The aim of this work was to evaluate the genetic status of the Girgentana goat, an endangered breed from Sicily (Italy), using microsatellite markers. Furthermore, as the main purpose of the Girgentana breed is milk production, quantitative milk traits were investigated, including fatty acid profile. Molecular data from CSN1S1, CSN2, CSN1S2, and CSN3 casein genes were also used to infer haplotypes. A total of 264 individuals were collected. Samples of Maltese $(n=41)$ and Derivata di Siria $(n=33)$ goat breeds were also used to understand the genetic relationship among breeds. Testday records for milk production were collected to determine daily milk yield, fat, protein, casein, lactose, and somatic cell count. Individual milk samples were also collected for fatty acid extraction. Wright's statistics, gene flow, Nei genetic distance, factorial correspondence analysis, and Bayesian assignment test showed the existence of genetic variability and differentiation among breeds. The AMOVA results indicated that $89.96 \%$ of the total variance was partitioned within populations. The Girgentana breed appears to have a subdivided population, and has not experienced a recent bottleneck. A high variability in milk yield was observed. Mean morning milk yield was $1448 \pm 404 \mathrm{~g}$, with $4.30 \pm 0.87 \%$ and $3.72 \pm 0.44 \%$ of fat and protein percentages, respectively. The average somatic cell count found in Girgentana goat milk was higher than the threshold of 1500000 cells $/ \mathrm{mL}$ advised in Europe for fresh milk. Gross milk and fatty acid composition were similar to that reported in the literature for other local goat breeds.
\end{abstract}

Additional keywords: casein genes, microsatellite markers, milk yield and gross composition.

Received 7 August 2015, accepted 25 November 2015, published online 22 March 2016

\section{Introduction}

In recent years, there has been great interest in recovering and preserving local livestock breeds and populations (e.g. Cornale et al. 2014; Vahidi et al. 2014; Parejo et al. 2015), considering that the existence of a large gene pool is important for preservation of potential future breeding and development of sustainable animal production systems.

Effective management of farm animal resources requires comprehensive knowledge of the breeds' characteristics (Groeneveld et al. 2010). Such exhaustive overview represents the starting point for the development of a preservation program. Molecular tools allow the characterisation of genetic resources at DNA level. Because of favourable characteristics, such as abundant number, high polymorphism and codominant inheritance, microsatellite DNA markers have been extensively used for several applications in livestock genetics (e.g. Tolone et al. 2012; Rosa et al. 2013; Vahidi et al. 2014; Parejo et al. 2015), and remain a choice for animal biodiversity studies of local breeds (Pons et al. 2015).

Many autochthonous breeds have an endangered status, or they even face extinction, because of their replacement by highly productive foreign breeds and progressive abandoning of low income rural activities. An interesting situation is represented by the Girgentana goat, an ancient local breed reared in Sicily. Over recent years, this breed has become almost extinct, in part as a consequence of the marked decrease in fresh goat milk consumption. In fact, it is listed by the Food and Agriculture Organisation with an endangered risk status (Canón et al. 2006).

The aim of this work was to evaluate the genetic status of the Girgentana goat breed using molecular information generated from microsatellite markers. Furthermore, as the main purpose of this breed is milk production, quantitative milk traits were investigated, including fatty acid (FA) profile. Molecular data from casein genes were also used to infer haplotypes.

\section{Materials and methods}

Biological samples

A total of 264 samples of the Girgentana goat breed enrolled in the Herd Book were randomly collected in several flocks located in four different areas of Sicily (Area $1=$ Palermo, Area $2=$ Agrigento, Area $3=$ Enna, and Area $4=$ Caltanissetta). In addition, samples of Maltese $(n=41)$ and Derivata di Siria 
( $n=33$ ) goat breeds were used to understand the genetic relationship among breeds. From each animal $\sim 10 \mathrm{~mL}$ of blood were collected from the jugular vein, using vacuum tubes containing EDTA as anticoagulant. Genomic DNA was extracted from buffy coats of nucleated cells using a salting out method (Miller et al. 1988). After checking the quantity and quality of DNA using a NanoDrop ND-1000 spectrophotometer (NanoDrop Technologies, Wilmington, DE, USA), samples were diluted to a final concentration of $50 \mathrm{ng} / \mu \mathrm{L}$ in ultrapure water and stored at $4^{\circ} \mathrm{C}$ until use.

\section{Microsatellite amplifications}

A total of 20 microsatellite markers were chosen according to the International Society for Animal Genetics and Food and Agriculture Organisation guidelines, in order to be polymorphic and to map all over the genome. Genotypes were determined by means of five multiplex fluorescent polymerase chain reactions (PCR) and fragment lengths determined in a single semiautomated electrophoresis run by using an ABI PRISM 3130xl Genetic Analyser and GeneMapper 4.0 with recommended protocols (Applied Biosystems, Foster City, CA, USA). Each PCR reaction was performed in a total volume of $10 \mu \mathrm{L}$ containing $100 \mathrm{ng}$ of genomic DNA, 1X PCR buffer with $\left(\mathrm{NH}_{4}\right)_{2} \mathrm{SO}_{4}, 2.5 \mathrm{mM} \mathrm{MgCl}, 0.8 \mathrm{mM}$ dNTPs, primers mix and $1 \mathrm{U}$ of Taq DNA polymerase (Fermentas, Hanover, MD, USA). The thermal cycling conditions were an initial denaturation at $95^{\circ} \mathrm{C}$ for $10 \mathrm{~min}, 35$ cycles of $95^{\circ} \mathrm{C}$ for $1 \mathrm{~min}, 56^{\circ} \mathrm{C}$ for $1 \mathrm{~min}$, and $72^{\circ} \mathrm{C}$ for $2 \mathrm{~min}$, followed by final extension at $60^{\circ} \mathrm{C}$ for $30 \mathrm{~min}$.

To evaluate data quality and repeatability, a total of five samples per breed were genotyped in duplicate. Moreover, to ensure correct genotype scoring, visual inspection was carried out independently by two experienced operators.

\section{Genetic variability of microsatellite markers in Girgentana breed}

Number of alleles per locus (k), observed and expected heterozygosity $\left(\mathrm{H}_{\mathrm{o}}\right.$ and $\mathrm{H}_{\mathrm{e}}$, respectively), polymorphic information content, Hardy-Weinberg equilibrium (HWE) and null allele frequencies for Girgentana breed were estimated using Cervus version 3.0.3 (Kalinowski et al. 2007).

\section{Genetic differentiation among breeds}

Wright's fixation indices among breeds $\left(F_{\text {is }}, F_{\text {it }}\right.$ and $\left.F_{\text {st }}\right)$ were estimated with FSTAT version 2.9.3 (Goudet 1995) using the Weir and Cockerham method (Weir and Cockerham 1984). The average number of effective migrants exchanged per generation (gene flow, Nm) was calculated with the following formula: $\mathrm{Nm}=\left(1-F_{\text {st }}\right) /\left(4 F_{\text {st }}\right)$, as applied in Genetix version 4.03 (Belkhir et al. 1996). Moreover, the same software was used to perform factorial correspondence analysis (FCA) based on the individual multilocus and genetic distances (Nei minimum distance). Analyses on Nm and FCA were applied among breeds (Girgentana, Maltese, and Derivata di Siria) and among four different groups of Girgentana goats corresponding to the four different sampling areas. The significance of the fixation indices was tested using Arlequin version 3.11 (Excoffier et al. 2005) through the locus-by-locus analysis of molecular variance (AMOVA) procedure among breeds. Bayesian model-based clustering method implemented in Structure version 2.3.1 (Pritchard et al. 2000) was used to analyse the genetic structure, identify the true number of populations and assign the individuals to each cluster $(K)$. The number of assumed clusters ranged from 1 to 7 . The model used was based on an assumption of admixture and correlated allele frequencies. For each $K, 50$ independent runs were performed. All runs consisted of a burn-in period of 10000 steps, followed by 100000 Markov Chain Monte Carlo iterations. The most likely number of $K$ clusters fitting the observed data was established by plotting $\operatorname{Ln} \operatorname{Pr}(\mathrm{G} \mid K)$ values obtained in the 50 independent runs for each $K$, as suggested by Pritchard et al. (2000). Following Evanno et al. (2005), we also calculated Delta $\mathrm{K}(\Delta K)$, an ad hoc statistic based on the second order rate of change of the likelihood function, $L^{\prime \prime}(K)$, with respect to $K$. Graphic representation of these statistics were obtained with the web-based Structure Harvester program (Earl and vonHoldt 2012). Finally, the bottleneck hypothesis on Girgentana breed was investigated using Bottleneck version 1.2.2 (Cornuet and Luikart 1996). Two-phase mutation model and the Wilcoxon signed-rank test were used to detect the possible presence of a recent bottleneck. This approach is considered the most appropriate for microsatellite markers (Piry et al. 1999). The qualitative descriptor of the allele frequency distribution, 'modeshift' indicator, was also used for assessing distortion in allele frequency, indicative of possible bottleneck.

\section{Milk yield and gross composition}

Test-day (TD) records for milk production on Girgentana goat kidding from 2011 to 2013 were collected in four different flocks, following an A4 recording scheme (ICAR 2007). Samples were taken both from animals with known and unknown genotypes at microsatellite markers. The first TD record was performed 31 days after kidding. Milk from the first 30 days of lactation was suckled by the kids. All goats were milked manually twice a day and milk from morning and evening milking was collected to determine daily milk yield (MY), fat (FAT), protein (PRT), casein (CAS), lactose (LCT) and somatic cell count (SCC). Milk samples were analysed using a Combifoss 6000 (FOSS Electric, Hillerod, Denmark) instrument. The original information was edited to guarantee the quality of the data to be analysed. Records were removed from the dataset when information of TD for MY, FAT, PRT, CAS, LCT and SCC were missed. SCC was transformed as $\log$ value $\left(\mathrm{SCC}\left(\log _{10}\right)\right)$. After editing, the dataset consisted of 870 TD records of 302 goats. Statistical analysis was performed using the PROC UNIVARIATE procedure of SAS statistical package (SAS Institute Inc., Cary, NC, USA).

\section{Fatty acids analyses}

Individual milk samples were collected during lactation from 100 goats, homogeneous for milk production, days of lactation, bodyweight and diet. The milk sample of each goat was collected during the morning milking, immediately stored at $4{ }^{\circ} \mathrm{C}$ in a portable refrigerator, and transported to the laboratory of Dipartimento Scienze Agrarie e Forestali, University of Palermo, where it was lyophilised and frozen at $-20^{\circ} \mathrm{C}$ until analysis. Before analysis, the lyophilised milk sample was 
solubilised by adding a corresponding volume of ultrapure water. Milk samples were prepared following the RoseGottlieb's method (AOAC 1995) for FA extraction. For transesterification of lipids, $2 \mathrm{~N} \mathrm{KOH}$ in methanol was used; the FA methyl esters were analysed with a chromatographic method (Sağdıç et al. 2004). The determination of the FA profile was performed by gas chromatography SHIMADZU GC-2010 with flame ionisation detector. The FA methyl esters were injected into capillary column (Zebron ZB-WAX Plus $30 \mathrm{~m} \times 0$ :32-mm id, $0.2-\mathrm{mM}$ film), identified according to the retention times and quantified by calibration curves. The results of FA were expressed as $\mathrm{g} / 100 \mathrm{~g}$ FAT.

\section{Casein haplotypes}

Molecular data of casein (CAS) gene polymorphisms for Girgentana breed from our previous studies on CSN1S1 (Mastrangelo et al. 2013a), CSN2 (Tortorici et al. 2014), CSN1S2 (Palmeri et al. 2014), and CSN3 (Di Gerlando et al. 2015), were used to infer haplotypes. Haplotypes distributions were analysed using HAPLOTYPE procedures of SAS (SAS Institute Inc.). Haplotype frequencies were calculated under the null hypothesis of no linkage disequilibrium and under the alternative hypothesis of association between CAS genes.

\section{Results and discussion}

\section{Genetic variability of microsatellite markers in Girgentana goat breed}

Microsatellite markers with their chromosome number, primer sequences, allele size range, and multiplex set are reported in Table S1, available as supplementary material for this paper.
Table 1 shows the number of alleles $(\mathrm{k})$, observed and expected heterozygosities $\left(\mathrm{H}_{\mathrm{o}}\right.$ and $\mathrm{H}_{\mathrm{e}}$, respectively), polymorphic information content (PIC), the significance of HWE and null allele frequency. All microsatellites were polymorphic, except STAT5B*, which was monomorphic in Girgentana goat. A total of 129 alleles were detected across the 19 loci studied. The number of alleles per locus ranged from 2 (ETH225) to 11 $(B R N)$ with an overall mean number of alleles per locus of 6.79. The average $H_{o}$ across loci was $0.576 \pm 0.204$, with estimates per locus ranging from 0.137 (ETH225) to 0.977 (CSRD247). The average $\mathrm{H}_{\mathrm{e}}$ value was $0.604 \pm 0.203$ with a range between $0.141(E T H 225)$ and $0.865(B R N)$. Most markers had high levels of polymorphism with PIC ranging from 0.131 (ETH225) to $0.849(B R N)$, and among all microsatellites, 14 were highly informative (PIC $>0.50)$. Five microsatellites showed significant deviation from $\operatorname{HWE}(P<0.01)$ (Table 1$)$. In general, there may be several reasons for the deviations from $\mathrm{HWE}$, such as the largest differences between $\mathrm{H}_{\mathrm{e}}$ and $\mathrm{H}_{\mathrm{o}}(\mathrm{Sechi}$ et al. 2007; Rosa et al. 2013), the high Fis values (Nei 1987), and the high null allele frequencies.

The relatively low mean number of alleles per locus could be the consequence of past bottlenecks, which are known to affect more allelic richness than the level of genetic variability (Luikart and Cornuet 1998). The ETH225 marker was not informative and was not further considered because it only presented two alleles. The same result for this marker was reported by Gour et al. (2006) in Jamunapari goats. In this study, the number of alleles was indicative of polymorphism and the final number of chosen loci (18) were sufficient for assessing genetic diversity and useful for the planned objectives. Based on gene diversity $\left(\mathrm{H}_{\mathrm{e}}\right)$, the Girgentana breed showed a moderate genetic variation, but the average $\mathrm{H}_{\mathrm{e}}$ showed in this

Table 1. Number of alleles $(k)$, observed $\left(H_{0}\right)$ and expected $\left(H_{e}\right)$ heterozygosities, polymorphic information content (PIC), Hardy-Weinberg equilibrium (HWE) and null allele frequency (F(Null)) of each locus for Girgentana goat breed

ND, not detected; n.s., not significant; ***, $P<0.001$. A significant $P$-value indicates deviation from equilibrium

\begin{tabular}{lrcccrr}
\hline Locus & $\mathrm{k}$ & $\mathrm{H}_{\mathrm{o}}$ & $\mathrm{H}_{\mathrm{e}}$ & PIC & HWE & F(Null) \\
\hline FCB48 & 7 & 0.758 & 0.755 & 0.716 & n.s. & -0.0008 \\
FCB20 & 6 & 0.769 & 0.773 & 0.738 & n.s. & -0.0899 \\
BRN & 11 & 0.727 & 0.865 & 0.849 & $* * *$ & 0.0973 \\
CSRD247 & 6 & 0.977 & 0.614 & 0.542 & $* * *$ & 0.1583 \\
SRCRSP0005 & 8 & 0.720 & 0.711 & 0.660 & n.s. & -0.0099 \\
OLADRB & 10 & 0.738 & 0.803 & 0.779 & n.s. & 0.0416 \\
SRCRSP0008 & 5 & 0.563 & 0.586 & 0.506 & n.s. & 0.0206 \\
INRA104 & 3 & 0.455 & 0.444 & 0.347 & n.s. & -0.0132 \\
OARAE54 & 8 & 0.413 & 0.402 & 0.386 & n.s. & -0.0278 \\
MB099 & 3 & 0.183 & 0.203 & 0.184 & n.s. & 0.0316 \\
MCM73 & 6 & 0.514 & 0.576 & 0.523 & $* * *$ & 0.0998 \\
FCB11 & 6 & 0.606 & 0.821 & 0.794 & $* * *$ & 0.1536 \\
BM1329 & 9 & 0.633 & 0.644 & 0.613 & n.s. & 0.0070 \\
ETH225 & 2 & 0.137 & 0.141 & 0.131 & ND & 0.0131 \\
INRA023 & 8 & 0.624 & 0.687 & 0.631 & n.s. & 0.0490 \\
SRCRSP0024 & 8 & 0.488 & 0.506 & 0.477 & n.s. & 0.0253 \\
TCRGC4 & 5 & 0.709 & 0.689 & 0.632 & n.s. & -0.0120 \\
TGLA122 & 8 & 0.431 & 0.461 & 0.429 & n.s. & 0.0370 \\
MCM64 & 10 & 0.504 & 0.789 & 0.763 & $* * *$ & 0.2213 \\
Mean & 6.79 & $0.576 \pm 0.204$ & $0.604 \pm 0.203$ & $0.563 \pm 0.202$ & - & - \\
\hline
\end{tabular}


study was lower than those reported for Florida (0.688), Guadarrama (0.678) (Canón et al. 2006), Retinta Extremeña (0.709) (Parejo et al. 2015), Sarda (0.700), Argentata dell'Etna (0.740) (Negrini et al. 2012), Mascaruna (0.703) (Mastrangelo et al. 2013b), Sempione (0.690) and Vallesana (0.700) (Cornale et al. 2014) breeds. Several factors can contribute to decrease gene diversity, as high selection pressure, the use of artificial insemination and uncontrolled mating of related individuals. In local breeds such as the Girgentana one, selection programs are absent, but natural mating is the common practice, and the exchange of males among herds is quite unusual (Mastrangelo et al. 2012). This leads to an increase of inbreeding within the population due to mating among relatives and could generate population subdivision as a consequence of genetic drift.

\section{Genetic differentiation among breeds}

Wright's statistics, gene flow (Nm), Nei standard genetic distance, FCA, and Bayesian model-based clustering algorithm were used to visualise and explore the genetic relationships among breeds using genotypic data from Maltese and Derivata di Siria goat breeds.

Wright's statistics among populations were: $F_{\text {is }}=0.052$ (within-population inbreeding estimate), $F_{\text {it }}=0.160$ (total inbreeding estimate) and $F_{\text {st }}=0.112$ (measurement of population differentiation). The $F_{\text {st }}$ indicated the existence of genetic differentiation among populations, as reported in a previous study on phylogenetic analysis of Sicilian goats using mitochondrial hypervariable region 1 (Sardina et al. 2006). The separation of Girgentana from the other goat breeds was also reported by Siwek et al. (2011) $\left(F_{\text {st }}=0.10\right)$ probably due to the differences in breeding system and origin. Moreover, the reduction in the numbers of reared animals could increase the genetic differentiation due to genetic drift. The lowest genetic distance (Nei) was between Maltese and Derivata di Siria due to geographic proximity, similarities in environment, breeding practices, and past gene flow among them. These two breeds showed a higher value of Nm (Table 2) than to the Girgentana breed, confirming the presence of a shared genetic background. However, in general, the results showed low gene flow among these breeds.

Wright's $F_{\text {is }}$ coefficient was also estimated per locus and across loci per breed (Table S2). The $F_{\text {is }}$ values per microsatellite marker in each breed ranged from -0.584 to 0.647. The lowest mean value was found in Girgentana $(0.037 \pm 0.188)$, whereas the highest one was found in Maltese $(0.118 \pm 0.208)$. Similar results for the Girgentana breed was reported by Pariset et al. (2009) ( $\left.F_{\text {is }}=0.041\right)$ using single nucleotide polymorphisms. In a previous study on eight Italian goat breeds, Negrini et al. (2012) reported the highest

Table 2. Genetic relationship among breeds: gene flow (Nm) (above diagonal) and Nei standard genetic distance (below diagonal)

\begin{tabular}{lccc}
\hline Breed & Girgentana & Maltese & Derivata di Siria \\
\hline Girgentana & - & 1.95 & 1.85 \\
Maltese & 0.087 & - & 2.74 \\
Derivata di Siria & 0.087 & 0.077 & - \\
\hline
\end{tabular}

value of $F_{\text {is }}$ for Girgentana, but the number of analysed animals $(n=30)$ was very low compared with the sample size used in our study. It is interesting that an endangered breed such as Girgentana goat showed the lowest $F_{\text {is }}$ value. In fact, despite the numerical reductions of the herds, an appropriate level of genetic variability has been conserved, probably due to the random mating in the breed that helps to maintain the genetic variability.

AMOVA analysis was carried out to analyse the variation within and between breeds. The AMOVA results indicated that $89.96 \%$ of the total variance was partitioned among individuals of the same population (within population), whereas $10.24 \%$ of the total variance was explained by differences among individuals from different populations (among populations), respectively (Table 3).

Genetic relationship between individuals was investigated using FCA that was performed including the three breeds using the corresponding allele frequencies (Fig. 1). The first two components explained the $100 \%$ of the total inertia, $70.97 \%$ of which explained by Axis 1 and $29.03 \%$ explained by Axis 2. The results showed that the breeds formed nonoverlapping clusters and are clearly separated populations (Fig. 1). Moreover, the individuals of Maltese showed a more spread cluster probably due to fewer samples and a larger genetic spectrum than the other ones.

Gene flow and FCA were also performed only for the Girgentana breed taking into account the different sampling areas. Number of migrants per generation ranged from 4.13 to 10.44 (Table 4). The distribution of the individuals described by FCA (Fig. 2) was consistent with the geographical locations of the farms in which the samples were collected, confirming at the area level that differentiation of diversity in nuclear genomes of goat breeds contains a significant portion of geographic structure, as has already been reported by other authors (Canón et al. 2006; Vahidi et al. 2014).

Population structure, degree of admixture and number of subpopulations $(K)$ were assessed by Bayesian approach implemented by Structure. The program estimates the natural logarithm (Ln) of the probability (Pr) that a given genotype $(\mathrm{G})$ is part of a given population $(K)$. The $\operatorname{LnPr}(\mathrm{G} \mid K)$ increased from $K=2$ to $K=5$, and then decreased for $K=6$. For $K=5$, the $\operatorname{LnPr}(\mathrm{G} \mid K)$ was maximised and also mean variance of the $\mathrm{LnPr}(\mathrm{G} \mid K)$ estimates was the lowest one (Fig. $3 a$ ). The $\Delta \mathrm{K}$ statistics (Evanno et al. 2005) were also calculated and presented in Fig. $3 b$. This analysis is strongly dependent on the variability between the runs of each $K$. Maximal $\Delta \mathrm{K}$ occurred at $K=2$, with other peaks at $K=3$ and $K=5$. These results indicated that individuals were most likely separated into two genetically distinct clusters: Girgentana versus Maltese and Derivata di Siria. Other authors identified a similar

Table 3. Results of AMOVA for Girgentana, Maltese and Derivata di Siria goat breeds

\begin{tabular}{lccc}
\hline Source of variation & $\begin{array}{c}\text { Sum of } \\
\text { squares }\end{array}$ & $\begin{array}{c}\text { Variance } \\
\text { components }\end{array}$ & $\begin{array}{c}\text { Variation } \\
(\%)\end{array}$ \\
\hline Among populations & 2119.647 & 0.58229 & 10.04 \\
Within populations & 1741.000 & 5.21782 & 89.96 \\
\hline
\end{tabular}




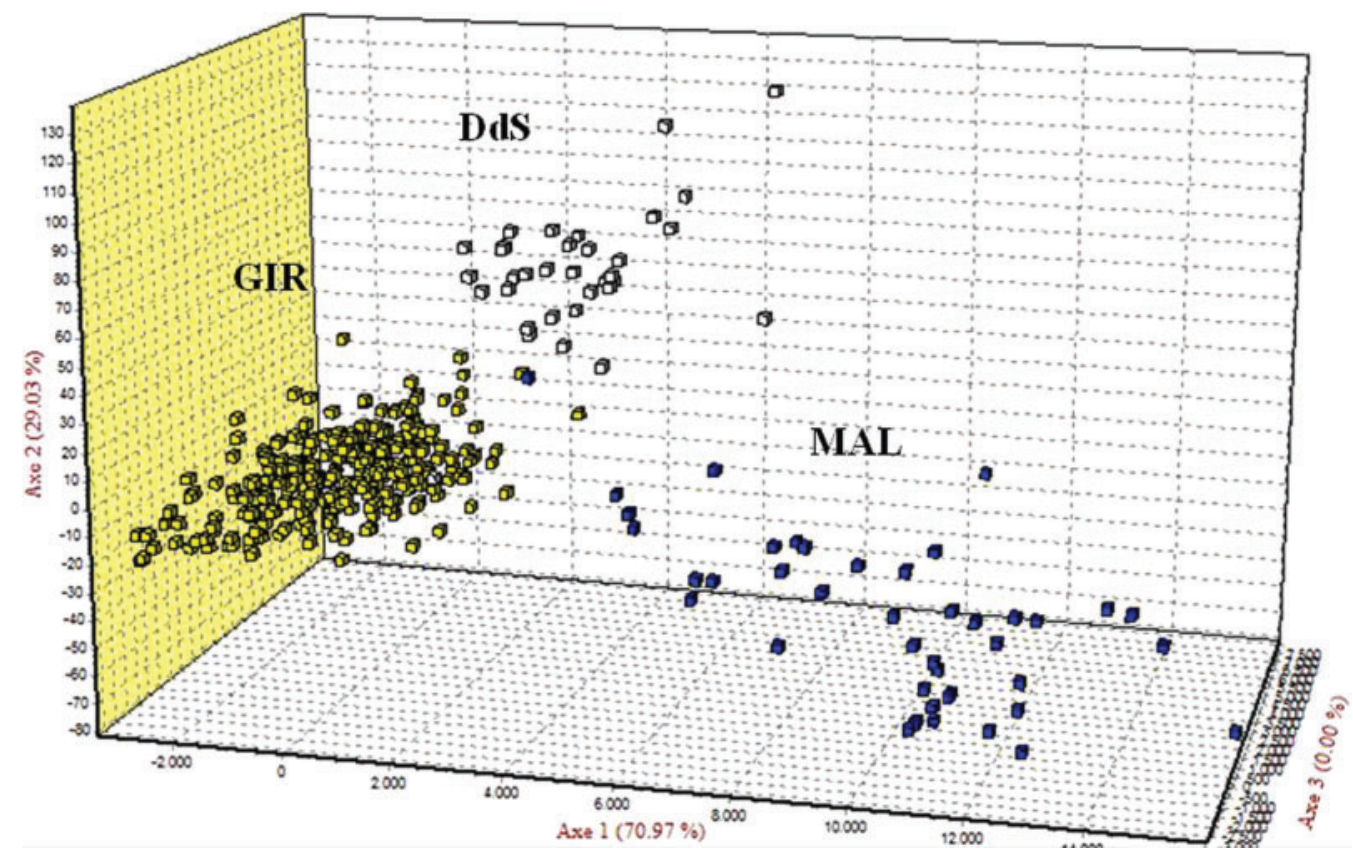

Fig. 1. Graphic representation of factorial correspondence analysis of Girgentana (GIR), Maltese (MAL) and Derivata di Siria (DdS) goat breeds. Numbers in parentheses represent the percentage of total inertia accounted by each axis.

Table 4. Gene flow (Nm) among individuals of Girgentana breed from different sampling areas

\begin{tabular}{lcccr}
\hline Breed & Area 1 & Area 2 & Area 3 & Area 4 \\
\hline Area 1 & - & 8.54 & 4.40 & 8.31 \\
Area 2 & - & - & 4.13 & 10.44 \\
Area 3 & - & - & - & 8.79 \\
Area 4 & - & - & - & - \\
\hline
\end{tabular}

discrepancy between methods, reporting that maximal $\Delta \mathrm{K}$ at $K=2$ to be an artefact (Vigouroux et al. 2008; Barreta et al. 2012). It is worth remembering that Evanno et al. (2005) insisted that the $\Delta \mathrm{K}$-based criterion should be used together with the other information provided by Structure. Therefore, based on this suggestion and the biological significance of the results, we considered that $K=5$ reflected the most likely number of clusters that optimally represented the data structure. Results of Structure analyses are shown in Fig. 4. Maltese and Derivata di Siria breeds maintained separate clusters, whereas the Girgentana showed a more complex structure because its genome was shared among subpopulations. Table 5 showed the assignment proportion of each breed to the five most likely inferred clusters. Clusters 1 and 5 included the Maltese and the Derivata di Siria individuals with $90.2 \%$ and $91.9 \%$, respectively. The results showed a significant proportion of assignment for these breeds and pointed out the existence of clear genetic differences between breeds, according to $F_{\text {st }}$ value. The Girgentana showed the highest level of genetic admixture with different proportion of individuals belonging to Cluster 2 (44.5\%), 3 (14.8\%) and 4 (37.7\%). Similar results were reported by Pariset et al. (2006) and Mastrangelo et al. (2013b). In fact, Sicilian goats have shown strong population admixture structure caused by geographical location of the farms, influences of natural mating and traditional breeding systems where the flock is an important breeding unit (Siwek et al. 2011). With the aim to know if Girgentana individuals grouped in the different clusters could respond with their sampling area, we marked the animals according to geographic area. In particular, animals from Areas 3 and 4 were assigned in Cluster 2, with some individuals from Area 2; in Cluster 4 were assigned individuals from Areas 1 and 2. Moreover, some individuals from Area 1 were assigned in Cluster 3. As expected, in general, individuals from the same area shared the same inferred cluster. Recently, Mastrangelo et al. (2014), in a study on local endangered cattle breeds using principal component analysis, showed that individuals that clustered together belonged to farms located in the same geographic area. The analysis with Structure software was consistent with the FCA results, confirming that the grouping of the animals in the detected clusters was correlated with their sampling area.

\section{Bottleneck}

For the conservation of genetic resources, the identification of populations that have experienced a size reduction is crucial, because a bottleneck can increase demographic stochasticity, rate of inbreeding, loss of genetic variation and fixation of deleterious alleles, thereby reducing the evolutionary potential and increasing the probability of population extinction (Negrini et al. 2012).

In order to test if reductions in population size have left a detectable signature in the nuclear genome, the two-phase mutation model under Wilcoxon signed-rank, sign and shift mode tests were used to investigate any recent bottleneck (heterozygosity excess) in the Girgentana goat breed. In a population at mutation-drift equilibrium, there is approximately 

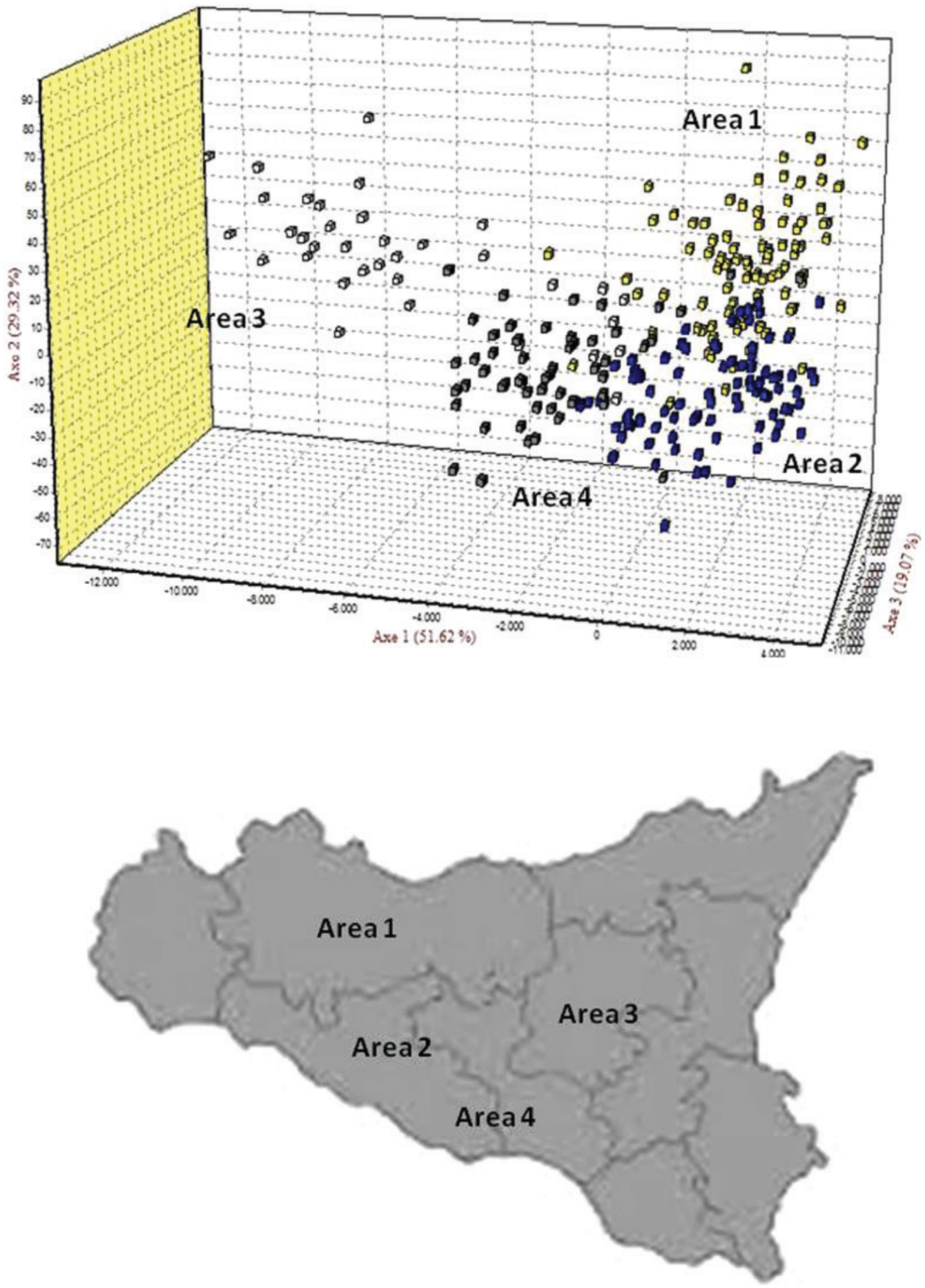

Fig. 2. Graphic representation of factorial correspondence analysis of Girgentana breed based on different areas in which the samples were collected. Numbers in parentheses represent the percentage of total inertia accounted by each axis.

an equal probability that a locus shows genetic diversity excess or deficit. The sign test (Cornuet and Luikart 1996) determines if a significant majority of loci in a population have a heterozygosity excess, and thus if a population appears to have been recently bottlenecked. Wilcoxon test provides relatively high power when less than 20 markers are used. In Girgentana breed, the expected number of markers displaying heterozygosity excess (10.37) was equal to the observed number of loci displaying heterozygosity excess (11), and greater than the observed number of loci with heterozygosity deficiency (7) (Table 6). The mode-shift indicator showed a normal L-shaped distribution in graphical representation proportion of allele versus class of 
frequency distribution (Fig. 5), which is expected for a population that has not experienced a recent bottleneck that affected genetic variability (Cornuet and Luikart 1996). Therefore, the analysis indicated that the Girgentana breed has not suffered any recent bottleneck (Table 6).

\section{Breed conservation}

The genetic diversity results presented here can be useful in outlining conservation strategies, even though it remains a
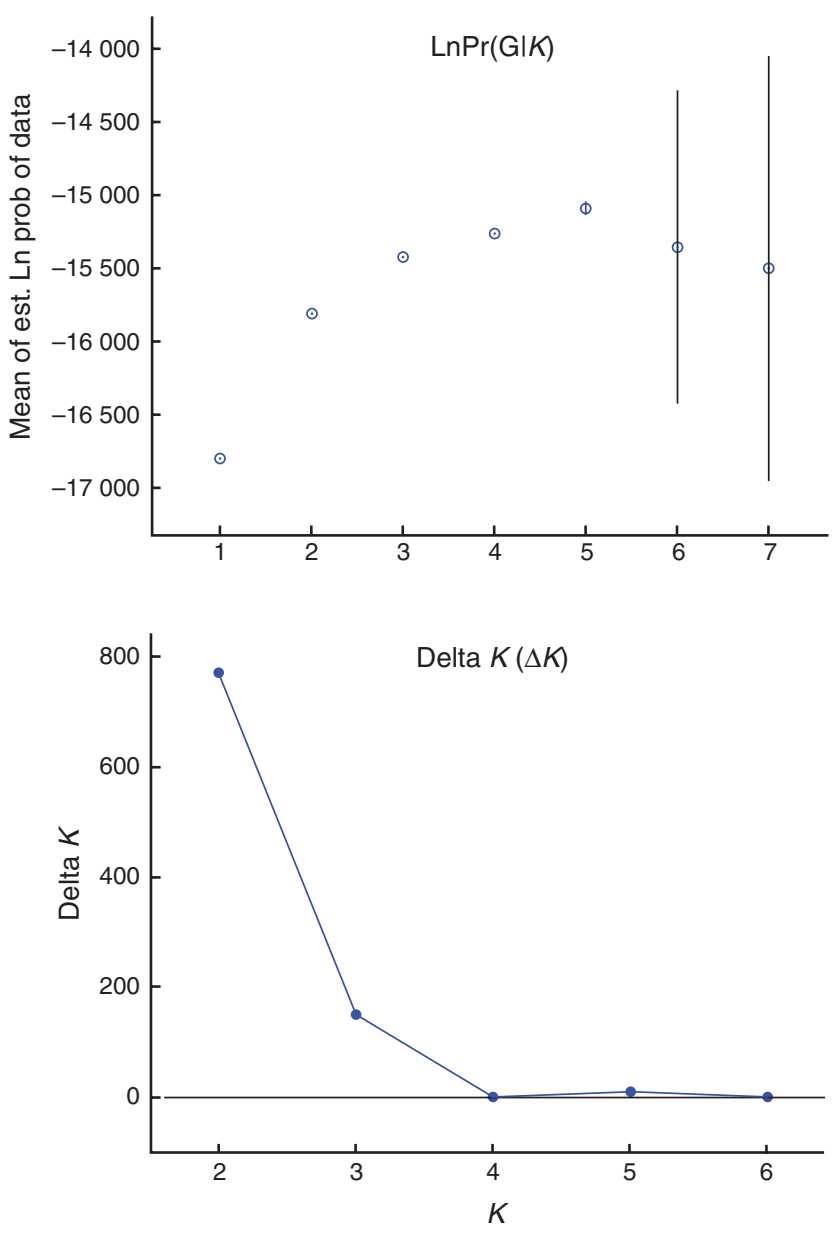

Fig. 3. Estimated posterior probabilities of $\operatorname{LnPr}(\mathrm{G} \mid K)$ : (a) $\operatorname{Ln} \operatorname{Pr}(\mathrm{G} \mid K)$ values are presented as a function of the number of clusters (Pritchard et al. 2000). Delta $K(\Delta \mathrm{K})$ values were calculated following Evanno et al. (2005). subject of discussion what are the optimum weights to be given to the between- and within-breed components of genetic diversity in defining conservation properties. Following the FAO (1998) guidelines, the recommended rules for the initial stages of a conservation program are maintaining genetic diversity, defining selection within families, and creating a nucleus population. The Girgentana breed appears to have a subdivided population. The conservation management of subdivided populations requires a compromise between the control of the global genetic diversity, the avoidance of high inbreeding levels, and, sometimes, the maintenance of a certain degree of differentiation between subpopulations (Fernández et al. 2008). The breed showed moderate levels of gene diversity (0.604) and inbreeding (0.037). Thus, the efforts should be made to improve genetic diversity in this breed. In particular, mating decisions will play an important role in limiting the levels of inbreeding and would increase the size of this breed. Minimisation of the loss of genetic variation is equivalent to minimisation of the rate of inbreeding in the population.

\section{Milk yield and gross composition}

The descriptive statistics for milk production traits were reported in Table 7. Moreover, to better understand the variability of milk composition, a boxplot was depicted in Fig. 6. A high variability in MY was observed: the recorded levels varied from less than 1000 to $\sim 4500 \mathrm{~g}$ /goat per day. The MY was higher than reported for Sarda goat breeds (Vacca et al. 2014), and lower than Garfagnina local goat breed (Martini et al. 2010). In a previous study, Todaro et al. (2005) reported lower MY $(704 \pm 323 \mathrm{~g})$, FAT $(3.93 \pm 1.23)$, and PRT $(3.48 \pm 0.38)$ percentages in Girgentana breed. Similar results were reported for indigenous Greek breeds (Kondyli et al. 2012). Coefficient of variation (CV) for FAT was high (20\%) compared with other milk production traits (Table 7) although MY had the highest $\mathrm{CV}$. In fact, FAT content is the more quantitatively and qualitatively variable component of milk, depending on lactation stage, season, breed, genotype and feeding (RaynalLjutovac et al. 2008).

Goat milk can display variable composition, which determines its use as drinking milk or for cheese making. This potentiality depends mainly on the milk PRT component and, more specifically, on the CAS fraction. Girgentana breed showed a proportion between CAS and PRT of $85 \%$. This feature makes the milk of this breed very suitable for the production of dairy products.

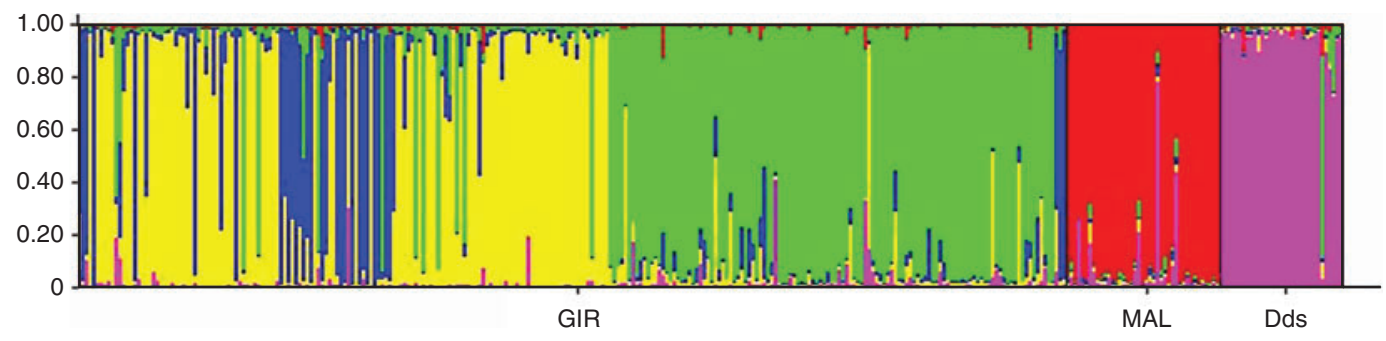

Fig. 4. Estimated population structure of the three goat breeds for $K$ ranging from 2 to 7: Girgentana (GIR), Maltese (MAL) and Derivata di Siria (DdS). The most likely $K$ was 5 . 
Table 5. Proportion of memberships of each breed in the five inferred clusters

\begin{tabular}{lccccc}
\hline Breed & \multicolumn{5}{c}{ Inferred clusters } \\
& 1 & 2 & 3 & 4 & 5 \\
\hline Girgentana & 0.010 & 0.445 & 0.148 & 0.377 & 0.019 \\
Maltese & 0.902 & 0.014 & 0.010 & 0.012 & 0.061 \\
Derivata di Siria & 0.016 & 0.043 & 0.008 & 0.014 & 0.919 \\
\hline
\end{tabular}

Table 6. Bottleneck analysis for Girgentana goat breed using the twophase mutation model (TPM) under Sign test and Wilcoxon rank test Hee, heterozygosity excess expected; Hd, heterozygosity deficiency; He, heterozygosity excess

\begin{tabular}{lll}
\hline Model & Sign test & Wilcoxon test \\
\hline TPM $^{\mathrm{A}}$ & Hee $=10.37$ & $P$ (one tail for H deficiency): 0.72456 \\
& $\mathrm{Hd}=7$ & $P$ (one tail for H excess): 0.28992 \\
& $\mathrm{He}=11$ & $P$ (two tails for H excess or deficiency): 0.57984 \\
& $P=0.48085$ & -
\end{tabular}

${ }^{\mathrm{A}}$ Parameters for TPM: variance $=30.00$ proportion of Stepwise Mutation Model in TPM $=70.00 \%$; estimation based on 1000 replications.

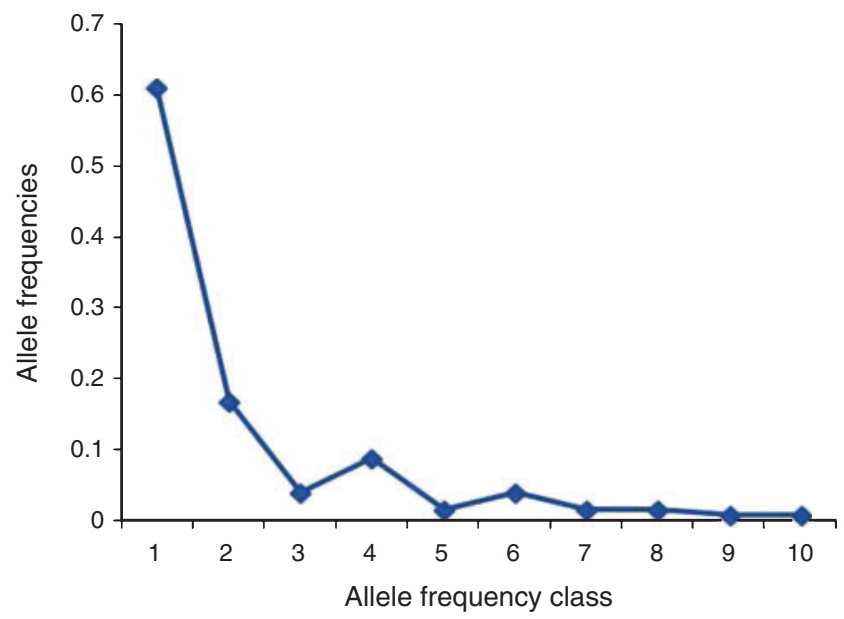

Fig. 5. L-shaped mode-shift graph of proportion of alleles and their distribution in Girgentana goat breed.

Although the threshold for SCC in goat's milk has not yet been established, the average SCC found in Girgentana goat milk, before being transformed into log value, was greater than the threshold of 1500000 cells/mL advised in Europe for fresh milk (Delgado-Pertiñez et al. 2003), with a high variability in our population (Table 7). Morgan et al. (2003) showed high mean levels of SCC in Greek goats $\left(3210 \times 10^{3}\right.$ cells $\left./ \mathrm{mL}\right)$ in the middle of lactation. Todaro et al. (2005) reported a mean value of 426000 cells $/ \mathrm{mL}$ for Girgentana goat. Similar mean values of SCC $\left(\log _{10}\right)$ were reported by Vacca et al. (2010) in local Sarda goat breed that, as Girgentana, is reared in a pastoral system, hand-milked and in the absence of modern husbandry techniques. High SCC in milk was associated with subclinical mastitis (Leitner et al. 2004) and it leads to modification of main milk components with negative effects on cheese manufacture. Therefore, more attention should be given to subclinical
Table 7. Descriptive statistics of yield and composition of Girgentana goat milk

\begin{tabular}{lcccc}
\hline Traits & Mean \pm s.d. & Max. & Min. & $\begin{array}{c}\text { Variation } \\
\text { coefficient (\%) }\end{array}$ \\
\hline Milk yield (g) & $1448 \pm 404$ & 4544 & 508 & 28 \\
Fat (\%) & $4.30 \pm 0.87$ & 7.69 & 1.82 & 20 \\
Protein (\%) & $3.72 \pm 0.44$ & 6.48 & 2.44 & 12 \\
Casein (\%) & $3.06 \pm 0.41$ & 5.19 & 1.87 & 13 \\
Lactose (\%) & $4.69 \pm 0.25$ & 5.52 & 3.54 & 5 \\
Somatic cell count $\left(\log _{10}\right)$ & $5.78 \pm 0.61$ & 7.28 & 4.47 & 11 \\
\hline
\end{tabular}

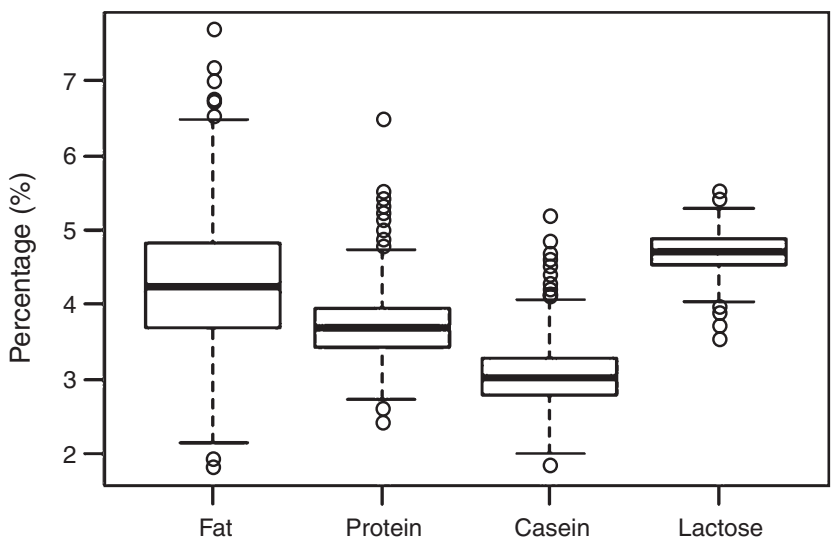

Fig. 6. Box plots with percentage (\%) of fat, protein, casein and lactose in Girgentana goat milk.

mastitis control and treatment programs for the improvement of udder health status in the Girgentana goat breed.

\section{Fatty acids analyses}

Thirteen FA were separated and quantified. The FA composition of Girgentana milk was reported in Table 8. A direct comparison of our results with those from the literature is quite difficult because the contents of FA are expressed in different units, and authors do not always state the breed, lactation period, and number of analysed samples. The most abundant FA was C16:0 followed by $\mathrm{C} 18: 1 c 9, \mathrm{C} 14: 0, \mathrm{C10} 0$ and $\mathrm{C} 18: 0$, which accounted for more than $75 \%$ of total FA, according to previous studies on Italian local goat breeds (Martini et al. 2010; Cornale et al. 2014). In milk of the Girgentana goat, caproic (C6:0), caprylic $(\mathrm{C} 8: 0)$, and capric (C10:0) acids accounted on average for 1.52, 2.55, and $11.38 \mathrm{~g} / 100 \mathrm{~g} \mathrm{FAT}$, respectively. These FA, are the most characteristic FA in goat milk and derived dairy products, being more abundant than in cow milk FAT, and with lauric acid (C12:0) are associated with the characteristic flavours of cheeses and can also be used to detect admixtures of milk from different species (Park et al. 2007). Moreover, odd- and branchedchain FA are also responsible for the typical aroma of caprine milk and cheese. The sum of short- and medium-chain FA (C4:0 to $\mathrm{C} 14: 0)$ was $34.97 \mathrm{~g} / 100 \mathrm{~g}$ FAT.

\section{Casein haplotypes}

Knowledge of variation of CAS genes at the haplotype level has been a useful tool in biodiversity studies and in breeding 
Table 8. Average fatty acid composition ( $g / 100 \mathrm{~g}$ fat) in milk of Girgentana breed

\begin{tabular}{|c|c|c|}
\hline \multirow[t]{2}{*}{ Fatty acid } & \multicolumn{2}{|c|}{ g $100 / \mathrm{g}$ fat } \\
\hline & Mean & s.d. \\
\hline $\mathrm{C} 4: 0$ & 0.40 & 0.12 \\
\hline C6:0 & 1.52 & 0.48 \\
\hline C8:0 & 2.55 & 0.19 \\
\hline C10:0 & 11.38 & 2.71 \\
\hline C12:0 & 6.78 & 1.70 \\
\hline C14:0 & 12.34 & 0.90 \\
\hline$\sum \mathrm{C} 4-\mathrm{C} 14$ & 34.97 & 3.37 \\
\hline C16:0 & 28.87 & 1.96 \\
\hline C16:1 & 0.18 & 0.09 \\
\hline $\mathrm{C} 17: 0$ & 0.18 & 0.09 \\
\hline $\mathrm{C} 18: 0$ & 8.03 & 1.73 \\
\hline $\mathrm{C} 18: 1 \mathrm{cis}-9$ & 13.88 & 2.37 \\
\hline C18:3 & 0.17 & 0.08 \\
\hline C20:0 & 0.26 & 0.04 \\
\hline
\end{tabular}

Table 9. Haplotype frequencies in the Girgentana breed. Haplotype frequencies were calculated both under hypothesis of loci independence (H0) and taking association into account (H1)

Only haplotypes with $\mathrm{H} 1$ frequency higher than 0.008 were shown

\begin{tabular}{lccccc}
\hline CSN1S1 & CSN2 & CSN1S2 & CSN3 & H0 & H1 \\
\hline A & C & A & A & 0.122 & 0.368 \\
F & C1 & F & B & 0.008 & 0.182 \\
F & C1 & A & A & 0.033 & 0.080 \\
A & C & A & D & 0.029 & 0.075 \\
A & 0 & A & B & 0.008 & 0.052 \\
N & C & A & B & 0.008 & 0.040 \\
A & C & C & D & 0.002 & 0.037 \\
B & C1 & A & N & 0.001 & 0.025 \\
A & C & A & B & 0.092 & 0.023 \\
B & A & A & A & 0.001 & 0.020 \\
A & C & F & B & 0.028 & 0.017 \\
F & C & F & B & 0.014 & 0.013 \\
N & C1 & F & B & 0.001 & 0.010 \\
\hline
\end{tabular}

strategies (Caroli et al. 2009). A total of 201 individuals of the Girgentana breed were used to infer haplotypes at CAS loci. Haplotype frequencies at CSN1S1-CSN2-CSN1S2-CSN3 loci were reported in Table 9. Of the 133 inferred haplotypes from the possible combinations of CAS genes, only 13 showed association frequencies higher than 0.008 . The predominant haplotype was the $A-C-A-A(36.8 \%)$, whereas the ancestral haplotype $B-A-A-B$ (Caroli et al. 2006) was not found in Girgentana due to the low frequency of $\operatorname{CSN}_{1 S 1}{ }^{*} B$ allele $(0.065)$ in this breed (Mastrangelo et al. 2013a). In a previous study Gigli et al. (2008) reported $A-C-A-B$ as the most frequent in Girgentana goat. These results may be explained considering the different allele frequency at $\operatorname{CSN}^{*} A$ reported by Di Gerlando et al. (2015) (0.480) compared with those reported in the previous study by Gigli et al. (2008) (0.127). In fact, the flocks are not the same of Gigli et al. (2008) and number of animals within flocks has changed during these past years, and then, the individual analysed samples are not the same of previous work. Moreover, different genotyping protocols were used. In fact, the CSN3 gene was genotyped using the Sanger sequencing protocol by Di Gerlando et al. (2015), whereas Gigli et al. (2008) used the PCR-single-strand conformation polymorphism protocol. The second most frequent haplotype was $F-C l-F-B(18.2 \%)$ recently reported in two Italian local goat breeds but with lower frequencies (Martini et al. 2010; Cornale et al. 2014). The first five haplotypes represented more than $75 \%$ of the CAS cluster variability. The Girgentana goat was characterised by an interesting and wide variability in the CAS cluster, with haplotypes rarely found in other breeds ( $N-C-A-B$ and $N-C 1-F-B$ ) containing the $N$ allele at the CSNIS1 locus, which has reported in few breeds, such as Tunisian goats (Vacca et al. 2009). It is well known that goat CAS are characterised by different expression levels due to strong, medium, weak or null alleles responsible for high, medium, or low CAS content in milk, depending on the CAS fraction (Caroli et al. 2006). Haplotype analysis of the CAS genes allows for selection of goat genetic lines for milk production with 'particular' PRT content (Sacchi et al. 2005). The high frequency of haplotypes containing strong alleles at each CAS gene indicates that selection for these variants should be an easy breeding objective to improve milk composition and cheese-making properties in the Girgentana breed (Martini et al. 2010). However, the occurrence of haplotype combinations with null and weak alleles, as $N$ and $F$ at CSNISI and $0^{1}$ at CSN2 loci, encloses a high productive potential, because goats carrying these alleles may produce milk with low PRT content, which can be used for fresh milk consumption, potentially reducing the risk of developing food allergies (Bevilacqua et al. 2002; Martini et al. 2010; Ballabio et al. 2011).

\section{Acknowledgement}

This work was supported by Rural Development Program, PSR 2007-2013, Misura 1.2.4, by Sicilia Region, Italy, Grant No. CUPG66D11000039999.

\section{References}

AOAC (1995) 'Official methods of analysis.' 16th edn. (Association Official Analytical Chemists: Arlington, VA)

Ballabio C, Chessa S, Rignanese D, Gigliotti C, Pagnacco G, Terracciano L, Fiocchi A, Restani P, Caroli AM (2011) Goat milk allergenicity as a function of alpha-s1-casein genetic polymorphism. Journal of Dairy Science 94, 998-1004. doi:10.3168/jds.2010-3545

Barreta J, Iñiguez V, Saavedra V, Romero F, Callisaya AM, Echalar J, Gutierrez-Gil B, Arranz JJ (2012) Genetic diversity and population structure of Bolivian alpacas. Small Ruminant Research 105, 97-104. doi:10.1016/j.smallrumres.2012.03.002

Belkhir K, Borsa P, Goudet J, Chikhi L, Bonhomme F (1996) GENETIX 4.05, logiciel sous WindowsTM pour la génétique des populations. Laboratoire Génome Populations, Interactions CNRS UMR 5000. Université de Montpellier II, Montpellier, France.

Bevilacqua C, Ferranti P, Garro G, Veltri C, Lagonigro R, Leroux C, Pietrola E, Addeo F, Pilla F, Chianese L, Martin P (2002) Interallelic recombination is probably responsible for the occurrence of a new alpha-s1-casein variant found in the goat species. European Journal of Biochemistry 269, 1293-1303. doi:10.1046/j.1432-1033.2002.02777.x

Canón J, García D, García-Atance MA, Obexer-Ruff G, Lenstra JA, Ajmone-Marsan P, Dunner S ECONOGENE Consortium (2006) Geographical partitioning of goat diversity in Europe and the Middle East. Animal Genetics 37, 327-334. doi:10.1111/j.1365-2052.2006. 01461.x 
Caroli AM, Chiatti F, Chessa S, Rignanese D, Bolla P, Pagnacco G (2006) Focusing on the goat casein complex. Journal of Dairy Science 89, 3178-3187. doi:10.3168/jds.S0022-0302(06)72592-9

Caroli AM, Chessa S, Erhardt GJ (2009) Invited review: milk protein polymorphisms in cattle: effect on animal breeding and human nutrition. Journal of Dairy Science 92, 5335-5352. doi:10.3168/jds. 2009-2461

Cornale P, Renna M, Lussiana C, Bigi D, Chessa S, Mimosi A (2014) The Grey Goat of Lanzo Valleys (Fiurinà): breed characteristics, genetic diversity, and quantitative-qualitative milk traits. Small Ruminant Research 116, 1-13. doi:10.1016/j.smallrumres.2013.10.006

Cornuet JM, Luikart G (1996) Description and power of two tests for detecting recent population bottlenecks from allele frequency data. Genetics 144, 2001-2014.

Delgado-Pertiñez M, Alcade MJ, Guzmán-Guerrero JL, Castel JM, Mena Y, Caravaca F (2003) Effect of hygiene-sanitary management on goat milk quality in semi-extensive system in Spain. Small Ruminant Research 47, 51-61. doi:10.1016/S0921-4488(02)00239-0

Di Gerlando R, Tortorici L, Sardina MT, Monteleone G, Mastrangelo S, Portolano B (2015) Molecular characterization of $\kappa$-casein (CSN3) gene in Girgentana dairy goat breed and identification of two new alleles. Italian Journal of Animal Science 14, 90-93. doi:10.4081/ ijas.2015.3464

Earl DA, vonHoldt BM (2012) STRUCTURE HARVESTER: a web-site and program for visualizing STRUCTURE output and implementing the Evanno method. Conservation Genetics Resources 4, 359-361. doi:10.1007/s12686-011-9548-7

Evanno G, Regnaut S, Goudet J (2005) Detecting the number of cluster of individuals using the software STRUCTURE: a simulation study. Molecular Ecology 14, 2611-2620. doi:10.1111/j.1365-294X.2005. 02553.x

Excoffier L, Laval G, Schneider S (2005) Arlequin ver. 3.0: an integrated software package for population genetics data analysis. Evolutionary Bioinformatics 1, 47-50.

FAO (1998) Secondary Guidelines for Development of National Farm Animal Genetic Resources Management Plans. Rome.

Fernández J, Toro MA, Caballero A (2008) Management of subdivided populations in conservation programs: development of a novel dynamic system. Genetics 179, 683-692. doi:10.1534/genetics.107. 083816

Gigli I, Maizon DO, Riggio V, Sardina MT, Portolano B (2008) Casein haplotype variability in Sicilian dairy goat breeds. Journal of Dairy Science 91, 3687-3692. doi:10.3168/jds.2008-1067

Goudet J (1995) FSTAT (version 2.9.3): a computer program to calculate F-statistics. The Journal of Heredity 8, 485-486.

Gour DS, Malik G, Ahlawat SPS, Pandey AK, Sharma R, Gupta N, Gupta SC, Bisen PS, Kumar D (2006) Analysis of genetic structure of Jamunapari goats by microsatellite markers. Small Ruminant Research 66, 140-149. doi:10.1016/j.smallrumres.2005.07.053

Groeneveld LF, Lenstra JA, Eding H, Toro MA, Scherf B, Pilling D, Negrini R, Finlay EK, Jianlin H, Groeneveld E, Weigend S (2010) GLOBALDIV Consortium: genetic diversity in farm animals - a review. Animal Genetics 41, 6-31. doi:10.1111/j.1365-2052.2010. 02038.x

ICAR (2007) Recording guidelines. International agreement of recording practices. Approved by the General Assembly, 9 June 2006, Kuopio, Finland. International Committee for Animal Recording ICAR newsletter.

Kalinowski ST, Taper ML, Marshall TC (2007) Revising how the computer program CERVUS accommodates genotyping error increases success in paternity assignment. Molecular Ecology 16, 1099-1106. doi:10.1111/ j.1365-294X.2007.03089.x

Kondyli E, Svarnas C, Samelis J, Katsiari MC (2012) Chemical composition and microbiological quality of ewe and goat milk of native Greek breeds. Small Ruminant Research 103, 194-199.
Leitner G, Chaffer M, Shamay A, Shapiro F, Merin U, Ezra E, Saran A, Silanikove N (2004) Changes in milk composition as affected by subclinical mastitis in sheep. Journal of Dairy Science 87, 46-52. doi:10.3168/jds.S0022-0302(04)73140-9

Luikart G, Cornuet JM (1998) Empirical evaluation of a test for identifying recently bottlenecked population from allele frequency data. Conservation Biology 12, 228-237. doi:10.1046/j.1523-1739.1998.96388.x

Martini M, Salari F, Altomonte I, Rignanese D, Chessa S, Gigliotti C, Caroli A (2010) The Garfagnina goat: a zootechnical overview of a local dairy population. Journal of Dairy Science 93, 4659-4667. doi:10.3168/ jds.2010-3207

Mastrangelo S, Sardina MT, Riggio V, Portolano B (2012) Study of polymorphisms in the promoter region of ovine $\beta$-lactoglobulin gene and phylogenetic analysis among the Valle del Belice breed and other sheep breeds considered as ancestors. Molecular Biology Reports 39, 745-751. doi:10.1007/s11033-011-0794-2

Mastrangelo S, Sardina MT, Tolone M, Portolano B (2013a) Genetic polymorphism at the CSN1S1 gene in Girgentana dairy goat breed. Animal Production Science 53, 403-406. doi:10.1071/AN12242

Mastrangelo S, Tolone M, Sardina MT, Di Gerlando R, Portolano B (2013b) Genetic characterization of the Mascaruna goat, a Sicilian autochthonous population, using molecular markers. African Journal of Biotechnology 12, 3758-3767.

Mastrangelo S, Saura M, Tolone M, Salces-Ortiz J, Di Gerlando R, Bertolini F, Fontanesi L, Sardina MT, Serrano M, Portolano B (2014) The genomewide structure of two economically important indigenous Sicilian cattle breeds. Journal of Animal Science 92, 4833-4842. doi:10.2527/ jas.2014-7898

Miller SA, Dykes DD, Polesky HF (1988) A simple salting out procedure for extracting DNA from human nucleated cells. Nucleic Acids Research 16, 1215. doi:10.1093/nar/16.3.1215

Morgan F, Massouras T, Barbosa M, Roseiro L, Ravasco F, Kandarakis I, Bonnin V, Fistakoris M, Anifantakis E, Jaubert G, Raynal-Ljutovac K (2003) Characteristics of goat milk collected from small and medium enterprises in Greece, Portugal and France. Small Ruminant Research 47, 39-49. doi:10.1016/S0921-4488(02)00252-3

Negrini R, D’Andrea M, Crepaldi P, Colli L, Nicoloso L, Guastella AM, Sechi T, Bordonaro S, Ajmone-Marsan P ECONOGENE Consortium (2012) Effect of microsatellite outliers on the genetic structure of eight Italian goat breeds. Small Ruminant Research 103, 99-107. doi:10.1016/ j.smallrumres.2011.08.006

Nei M (1987) Analysis of gene diversity in subdivided populations. Proceeding of the National Academy of Science of the United States of America 70, 3321-3323.

Palmeri M, Mastrangelo S, Sardina MT, Portolano B (2014) Genetic variability at as2-casein gene in Girgentana dairy goat breed. Italian Journal of Animal Science 13, 116-118. doi:10.4081/ijas.2014.2997

Parejo JC, Padilla JA, Calero R, Martínez-Trancón M, Sansinforiano E, Rabasco A, Salazar J, Bravo JA (2015) Population genetic structure and conservation management of Retinta Extremeña goats. Small Ruminant Research 124, 9-16. doi:10.1016/j.smallrumres.2015.01.004

Pariset L, Cappuccio I, Ajmone-Marsan P, Dunner S, Luikart G, England PR, Obexer-Ruff G, Peter C, Marletta D, Pilla F, Valentini A Econogene Consortium (2006) Assessment of population structure by single nucleotide polymorphisms (SNPs) in goat breeds. Journal of Chromatography. B, Analytical Technologies in the Biomedical and Life Sciences 833, 117-120. doi:10.1016/j.jchromb.2006.01.011

Pariset L, Cuteri A, Ligda C, Ajmone-Marsan P, Valentini A ECONOGENE Consortium (2009) Geographical patterning of sixteen goat breeds from Italy, Albania and Greece assessed by Single Nucleotide Polymorphisms. BMC Ecology 9, 20. doi:10.1186/1472-6785-9-20

Park YW, Jurez M, Ramos M, Haenlein GFW (2007) Physico-chemical characteristics of goat and sheep milk. Small Ruminant Research 68, 88-113. doi:10.1016/j.smallrumres.2006.09.013 
Piry S, Luikart G, Cornuet JM (1999) BOTTLENECK: a computer program for detecting recent reductions in the effective population size using allele frequency data. The Journal of Heredity 90, 502-503. doi:10.1093/jhered/90.4.502

Pons AL, Landi V, Martinez A, Delgado JV (2015) The biodiversity and genetic structure of Balearic sheep breeds. Journal of Animal Breeding and Genetics 132, 268-276. doi:10.1111/jbg.12129

Pritchard JK, Stephens M, Donnelly P (2000) Inference of population structure using multilocus genotype data. Genetics 155, 945-959.

Raynal-Ljutovac K, Lagriffoul G, Paccard P, Guillet I, Chilliard Y (2008) Composition of goat and sheep milk products: an update. Small Ruminant Research 79, 57-72. doi:10.1016/j.smallrumres.2008.07.009

Rosa AJM, Sardina MT, Mastrangelo S, Tolone M, Portolano B (2013) Parentage verification of Valle del Belice dairy sheep using multiplex microsatellite panel. Small Ruminant Research 113, 62-65. doi:10.1016/ j.smallrumres.2013.03.021

Sacchi P, Chessa S, Budelli E, Bolla P, Ceriotti G, Soglia D, Rasero R, Cauvin E, Caroli A (2005) Casein haplotype structure in five Italian goat breeds. Journal of Dairy Science 88, 1561-1568. doi:10.3168/jds. S0022-0302(05)72825-3

Sağdıç O, Dönmez M, Demirci M (2004) Comparison of characteristics and fatty acid profiles of traditional Turkish yayik butters produced from goats', ewes' or cows' milk. Food Control 15, 485-490. doi:10.1016/j.foodcont.2003.07.003

Sardina MT, Ballester M, Marmi J, Finocchiaro R, Van Kaam JBC, Portolano B, Folch JM (2006) Phylogenetic analysis of Sicilian goats reveals a new mtDNA lineage. Animal Genetics 37, 376-378. doi:10.1111/j.1365-2052.2006.01451.x

Sechi T, Usai MG, Miari S, Mura L, Casu S, Carta A (2007) Identifying native animals in crossbred populations: the case of the Sardinian goat population. Animal Genetics 38, 614-620.

Siwek M, Finocchiaro R, Curik I, Portolano B (2011) Hierarchical structure of the Sicilian goats revealed by Bayesian analyses of microsatellite information. Animal Genetics 42, 93-95. doi:10.1111/j.1365-2052. 2010.02080.x
Todaro M, Scatassa ML, Giaccone P (2005) Multivariate factor analysis of Girgentana goat milk composition. Italian Journal of Animal Science 4, 403-410.

Tolone M, Mastrangelo S, Rosa AJM, Portolano B (2012) Genetic diversity and population structure of Sicilian sheep breeds using microsatellite markers. Small Ruminant Research 102, 18-25. doi:10.1016/j.smallrumres.2011.09.010

Tortorici L, Di Gerlando R, Mastrangelo S, Sardina MT, Portolano B (2014) Genetic characterization of CSN2 gene in Girgentana goat breed. Italian Journal of Animal Science 13, 720-722. doi:10.4081/ijas. 2014.3414

Vacca GM, Ali HOAB, Carcangiu V, Pazzola M, Dettori ML (2009) Genetic structure of the casein gene cluster in the Tunisian native goat breed. Small Ruminant Research 87, 33-38. doi:10.1016/j.smallrumres.2009. 09.034

Vacca GM, Dettori ML, Carcangiu V, Rocchigiani AM, Pazzola M (2010) Relationships between milk characteristics and somatic cell score in milk from primiparous browsing goats. Animal Science Journal 81, 594-599. doi:10.1111/j.1740-0929.2010.00774.x

Vacca GM, Dettori ML, Piras G, Manca F, Paschino P, Pazzola M (2014) Goat casein genotypes are associated with milk production traits in the Sarda breed. Animal Genetics 45, 723-731. doi:10.1111/age.12188

Vahidi SMF, Tarang AR, Naqvi AUN, Falahati AM, Boettcher P, Joost S, Colli L, Garcia JF, Ajmone-Marsan P (2014) Investigation of the genetic diversity of domestic Capra hircus breeds reared within an early goat domestication area in Iran. Genetics, Selection, Evolution. 46, 27. doi:10.1186/1297-9686-46-27

Vigouroux Y, Glaubitz JC, Matsuoka Y, Goodman MM, Sanchez GJ, Doebley J (2008) Population structure and genetic diversity of new world maize races assessed by DNA microsatellites. American Journal of Botany 95, 1240-1253. doi:10.3732/ajb.0800097

Weir BS, Cockerham CC (1984) Estimating F-statistics for the analysis of population structure. Evolution 38, 1358-1370. doi:10.2307/ 2408641 